\title{
Dysregulation of glucocorticoid metabolism in murine obesity: comparable effects of leptin resistance and deficiency
}

\author{
Dawn E W Livingstone, Sarah L Grassick, Gillian L Currie, Brian R Walker and Ruth Andrew \\ Endocrinology Unit, Queen's Medical Research Institute, Centre for Cardiovascular Science, University of Edinburgh, 47, Little France Crescent, \\ Edinburgh EH16 4TJ, UK \\ (Correspondence should be addressed to R Andrew; Email: ruth.andrew@ed.ac.uk)
}

\begin{abstract}
In obese humans, metabolism of glucocorticoids by $11 \beta$-hydroxysteroid dehydrogenase type $1(11 \beta$-HSD1) and A-ring reduction (by $5 \alpha$-and $5 \beta$-reductases) is dysregulated in a tissue specific manner. These changes have been recapitulated in leptin resistant obese Zucker rats but were not observed in high-fat fed Wistar rats. Recent data from mouse models suggest that such discrepancies may reflect differences in leptin signalling. We therefore compared glucocorticoid metabolism in murine models of leptin deficiency and resistance. Male $o b / o b$ and $d b / d b$ mice and their respective littermate controls ( $n=10-12$ /group) were studied at the age of 12 weeks. Enzyme activities and mRNA expression were quantified in snap-frozen tissues. The patterns of altered
\end{abstract}

pathways of steroid metabolism in obesity were similar in $o b / o b$ and $d b / d b$ mice. In liver, $5 \beta$-reductase activity and mRNA were increased and 11 $\beta$-HSD1 decreased in obese mice, whereas $5 \alpha$-reductase 1 ( $5 \alpha \mathrm{R} 1)$ mRNA was not altered. In visceral adipose depots, $5 \beta$-reductase was not expressed, $11 \beta$-HSD1 activity was increased and $5 \alpha \mathrm{R} 1 \mathrm{mRNA}$ was not altered in obesity. By contrast, in subcutaneous adipose tissue $11 \beta-H S D 1$ and $5 \alpha \mathrm{R} 1 \mathrm{mRNA}$ were decreased. Systematic differences were not found between $o b / o b$ and $d b / d b$ murine models of obesity, suggesting that variations in leptin signalling through the short splice variant of the $\mathrm{Ob}$ receptor do not contribute to dysregulation of glucocorticoid metabolism.

Journal of Endocrinology (2009) 201, 211-218

\section{Introduction}

Tissue-specific dysregulation of the glucocorticoid-generating enzyme $11 \beta$-hydroxysteroid dehydrogenase type 1 (11 $\beta$ HSD1) in rodent (Livingstone et al. 2000, Liu et al. 2003) and human obesity (Bujalska et al. 1997, Fraser et al. 1999, Rask et al. 2001) and the effects of $11 \beta-H S D 1$ deficiency (Morton et al. 2004) or inhibition (Alberts et al. 2002, Hermanowski-Vosatka et al. 2005) to protect against obesityassociated metabolic dysfunction, has supported the hypothesis that variations in glucocorticoid metabolism within target tissues play an important role in the pathophysiology of Metabolic Syndrome.

In addition to $11 \beta-H S D 1$, glucocorticoids are metabolised by several other enzymes (Fig. 1). In liver, glucocorticoids are inactivated by A-ring reductases $(5 \alpha$ - and $5 \beta$-reductases and $3 \alpha-\mathrm{HSD}$ ) and regenerated by $11 \beta-\mathrm{HSD} 1$ (Andrew $\&$ Walker 2002). The pattern of metabolism in adipose tissue is similar, with $5 \alpha$-reductase 1 ( $5 \alpha \mathrm{R} 1$ ), $3 \alpha-\mathrm{HSD}$ and $11 \beta$-HSD1 being expressed (Barat et al. 2007, Wake et al. 2007b). A-ring reductases are also dysregulated in obesity. In human obesity, whole body A-ring reduction is enhanced, as judged by urinary steroid excretion, increasing peripheral clearance of cortisol and (Andrew et al. 1998, Tomlinson et al. 2008) potentially inducing compensatory activation of the hypothalamic-pituitary-adrenal axis (Andrew et al. 1998, Rask et al. 2001, 2002). In leptin-resistant obese Zucker rats increased urinary $5 \alpha$-reduced metabolites can be accounted for by up-regulation of expression and activities of hepatic A-ring reductases (Livingstone et al. 2005). $5 \alpha \mathrm{R} 1$ is also expressed in adipose tissue but is not dysregulated in subcutaneous (s.c.) adipose in obese humans or rats (Barat et al. 2007, Wake et al. 2007b).

In studies of $11 \beta-H S D 1$, up-regulation of enzyme expression in adipose tissue and down-regulation in liver has not been a universal finding in obesity. For example, in diet-induced obesity in mice and rats adipose $11 \beta$-HSD 1 is down-regulated (Morton et al. 2004, Drake et al. 2005). Furthermore, leptin resistant and deficient mice have been shown by Liu et al. to have divergent changes in hepatic 11ß-HSD1 activity, with expression and activity being decreased in leptin deficient $o b / o b$ mice (Liu et al. 2003) but paradoxically increased in leptin resistant $d b / d b$ mice (Liu et al. 2005). These differences may reflect the distinctions between the defects in leptin signalling in these models.

Leptin signals through several splice variants of the leptin receptor (Ob-R; Lee et al. 1996). The long-form of the receptor $(\mathrm{Ob}-\mathrm{Rb})$ has an intracellular domain crucial to its signalling properties via Stat 3 , and is predominantly expressed in the hypothalamus, where it controls appetite regulation; this 


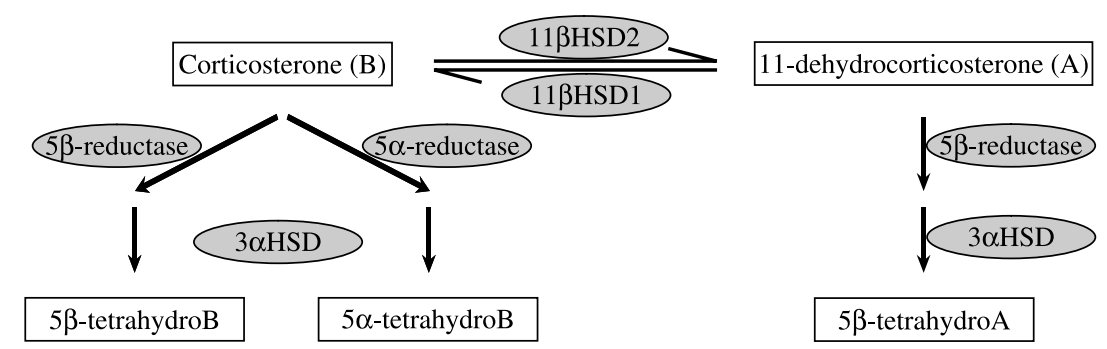

Figure 1 Glucocorticoid metabolic pathways. A is 11-dehydrocorticosterone; $B$ is corticosterone and HSD is hydroxysteroid dehydrogenase.

cytosolic region is truncated in the $d b / d b$ mouse (Lee et al. 1996, Sahai et al. 2004). A short form of the receptor lacking the intracellular domain (Ob-Ra) is expressed in the liver (Hoggard et al. 1997), where it can activate the inositol trisphosphate kinase cascade, thus potentially modulating insulin signalling pathways (Cohen et al. 1996, Zhao et al. 2000). Stimulation of Ob-Ra may occur in $d b / d b$ mice, but not in $o b / o b$ mice that lack circulating leptin. Indeed, Ob-Ra activation may be critical in the development of hepatic insulin resistance and non-alcoholic steatohepatitis (Sahai et al. 2004). It is possible that activation of Ob-Ra may be responsible for leptin-induced up-regulation of 11ß-HSD1 expression in hepatocytes (which lack Ob-Rb; Liu et al. 2005), and this mechanism may mediate up-regulation of liver $11 \beta-H S D 1$ in $d b / d b$ mice. This capacity for residual leptin signalling in $d b / d b$ mice is not predicted in Zucker obese rats, since the $f a$ mutation in the leptin receptor affects the extracellular domains of both Ob-Ra and b (Chua et al. 1996, Da Silva et al. 1998). We therefore hypothesised that deficient leptin signalling underlies dysregulation of hepatic glucocorticoid metabolism by $11 \beta-$ HSD 1 and A-ring reductases.

The aims of the present study were to explore glucocorticoid metabolism - not only by $11 \beta-$ HSD 1 but also by A-ring reductases - in murine models of obesity and, by comparing findings in $o b / o b$ and $d b / d b$ mice, to dissect the potential role of $\mathrm{Ob}-\mathrm{Ra}$ in mediating dysregulation of hepatic steroid metabolism in obesity.

\section{Materials and Methods}

\section{Materials}

All chemicals were obtained from Sigma unless otherwise stated. Solvents were glass distilled HPLC grade from Fisher Scientific (Loughborough, UK). Steroid standards were obtained from Steraloids (Newport, RI, USA). Radiolabelled-steroids were from GE Healthcare (Buckinghamshire, UK).

\section{Animals}

Male obese $\left(\operatorname{Lepr}^{\mathrm{DB}} / \operatorname{Lepr}^{\mathrm{DB}}(d b / d b)\right.$ and Lep $\left.{ }^{\mathrm{ob}} / \mathrm{Lep}^{\mathrm{ob}}(o b / o b)\right)$ mice and their respective lean heterozygote or wild-type littermates ( $\mathrm{Db} /$ ? and $\mathrm{Ob} /$ ?; C57BL background; Harlan,
Bicester, UK) were characterised by phenotype, maintained under controlled conditions of light (on 0700-1900 h) and temperature $\left(21^{\circ} \mathrm{C}\right)$, and allowed free access to standard chow (Special Diet Services, Witham, UK) and drinking water. At 12 weeks of age, they were decapitated at 0800-1100 h and tissues dissected and snap frozen on dry ice. All animal experiments were carried out under UK Home Office guidelines.

\section{Biochemical assays}

Glucose and insulin were measured by hexokinase (Thermo Electron, Melbourne, Australia) and ELISA (Crystal Chem Inc., Downers Grove, IL, USA) respectively. Hepatic triglycerides were measured spectrophotometrically (Microgenics, Passau, Germany) as previously reported (Raubenheimer et al. 2006). Corticosterone was quantified in plasma by in-house RIA (Holmes et al. 1995).

\section{$11 \beta$-HSD1 activity assay}

$11 \beta$-HSD1 is a reductase in vivo, converting inactive 11 -dehydrocorticosterone to corticosterone. However, in vitro dehydrogenase activity predominates and measurements of reductase activity are confounded by competition with other enzymes. Therefore, to estimate $11 \beta$-HSD1 protein, we measured enzyme activity as conversion of corticosterone to 11-dehydrocorticosterone in the presence of an excess of cofactor $\mathrm{NADP}^{+}$. Aliquots of tissues were homogenised in Krebs Ringer buffer as previously described (Livingstone et al. 2000), and protein concentrations determined colorimetrically using a Bradford kit (Bio-Rad). Standardised amounts of protein for each tissue were incubated in duplicate at $37^{\circ} \mathrm{C}$ in Krebs Ringer buffer containing $0 \cdot 2 \%$ glucose, $\mathrm{NADP}^{+}(2 \mathrm{mmol} / \mathrm{l}),\left[{ }^{3} \mathrm{H}\right]_{4}$-corticosterone $(10 \mathrm{nmol} / \mathrm{l})$ and unlabelled corticosterone $(1.99 \mu \mathrm{mol} / \mathrm{l})$. Protein concentrations and incubation times were optimised for each tissue to ensure first order kinetics (liver, $25 \mu \mathrm{g} / \mathrm{ml}$ per $\mathrm{h}$; adipose tissue, $100-200 \mu \mathrm{g} / \mathrm{ml}$ per $\mathrm{h}$ ). After incubation, steroids were extracted with ethyl acetate, the organic phase evaporated under nitrogen and extracts re-solubilised in mobile phase (water:acetonitrile:methanol; 60:15:25, $1.5 \mathrm{ml} / \mathrm{min})$. Steroids were separated by HPLC using a C18 
reverse phase Symmetry column $(4.6 \mathrm{~mm}, 15 \mathrm{~cm}, 5 \mu \mathrm{m}$; Waters, Elstree, UK) at $35^{\circ} \mathrm{C}$ and quantified by on-line liquid scintillation counting.

Owing to the paucity of intra-abdominal adipose tissue in lean mice, omental adipose tissue was used to quantify enzyme activity, whereas mesenteric adipose was used to quantify transcript abundance.

\section{$5 \beta$-Reductase activity assay}

Hepatic $5 \beta$-reductase $(5 \beta R)$ activity was assessed by the conversion of $\left[{ }^{3} \mathrm{H}\right]_{4}$-corticosterone to $\left[{ }^{3} \mathrm{H}\right]_{4}-5 \beta$-tetrahydrocorticosterone in hepatic cytosol (Livingstone et al. 2005). Enzyme velocity was measured by incubating cytosol in duplicate at $37^{\circ} \mathrm{C}$, in sodium phosphate buffer $\left(40 \mathrm{mmol} / 1 \mathrm{Na}_{2} \mathrm{PO}_{4}\right.$, $320 \mathrm{mmol} / 1$ sucrose, $1 \mathrm{mmol} / 1$ dithiothreitol, $\mathrm{pH} 7 \cdot 5$ ) containing NADPH (1 mmol/l), glucose-6-phosphate ( $5 \mathrm{mmol} / \mathrm{lM}$ ), glucose-6-phosphate dehydrogenase (1 unit/ml), $\left[{ }^{3} \mathrm{H}\right]_{4}$-corticosterone $(10 \mathrm{nmol} / \mathrm{l})$ and unlabelled corticosterone (1.99 $\mu \mathrm{mol} / \mathrm{l}$; Livingstone et al. 2005). Protein concentration and incubation period $(0.5 \mathrm{mg} / \mathrm{ml}$ for $24 \mathrm{~h})$ were optimised to ensure first order kinetics. Steroids were extracted with ethyl acetate, the organic phase was evaporated under nitrogen and extracts re-solubilised in mobile phase and analysed by HPLC as above.

\section{Quantification of $m R N A$ by real-time quantitative PCR}

Total RNA was extracted from snap-frozen tissue samples, and $500 \mathrm{ng}$ reverse transcribed into cDNA with random primers using the QuantiTect DNase/reverse transcription kit (Qiagen Ltd). cDNA (equivalent to $10 \mathrm{ng}$ total RNA) was incubated in triplicate with $1 \times$ gene specific assay mix (Applied Biosystems, Warrington, UK) in $1 \times$ LightCycler480 Probes mastermix (Roche Diagnostics Ltd). PCR cycling and detection of fluorescent signal was carried out using a Roche LightCycler480. A standard curve was constructed for each primer probe set using a serial dilution of cDNA pooled from all samples. For liver and adipose, results were corrected for $18 \mathrm{~S}$ and cyclophilin A RNA respectively, which were not different between groups. Assays used were: 11 $\beta$-HSD1, Mm00476182_m1; 5 $\alpha \mathrm{R} 1$, Mm00614213_m1; 5ßR, Mm00520266_m1; 18S, Hs99999 901_s1 and Cyclophilin A, Mm02342430_g1.

\section{Statistical analysis}

Data are mean \pm s.e.M. and groups $(n=10-12$ unless otherwise stated) were compared by Student's $t$-test.

\section{Results}

Both $d b / d b$ mice and $o b / o b$ mice were heavier than their respective control groups at the time of cull (Table 1), and had increased liver weight. Both $d b / d b$ and $o b / o b$ mice had higher circulating glucose, insulin and corticosterone and hepatic triglycerides than lean controls.

\section{Hepatic glucocorticoid metabolism}

Hepatic 11 $\beta$-HSD1 activity was lower in both $d b / d b$ and $o b / o b$ mice compared with lean controls (Fig. 2A and B), although mRNA for 11 $\beta$-HSD1 was not different in either model (Fig. 2E and F). 5 $\beta \mathrm{R}$ activity and transcript abundance were higher in both $d b / d b$ and $o b / o b$ mice compared with their controls (Fig. 2C-F). There was no difference in abundance of $5 \alpha \mathrm{R} 1 \mathrm{mRNA}$ between lean and obese animals of either strain (Fig. 2E and F). Activity of $5 \alpha \mathrm{R} 1$ was not measured due to instability of the protein (Eicheler et al. 1995).

\section{Glucocorticoid metabolism in adipose tissue}

In $d b / d b$ mice, activity of $11 \beta$-HSD1 was higher in retroperitoneal and omental adipose but lower in s.c. and epidydimal adipose compared with controls (Fig. 3A). In $o b / o b$ mice, $11 \beta$-HSD1 activity was higher in epididymal, retro-peritoneal and omental adipose but lower in s.c. adipose tissue compared with controls (Fig. 3B). Expression of $11 \beta$-HSD1 mRNA followed a similar pattern, in the main (Fig. 3C and D), although dysregulation of $11 \beta-H S D 1$ mRNA was not observed in epididymal adipose tissue. Note that in mesenteric adipose tissue, limited amounts of tissue in lean mice resulted in analysis of only $n=6$ samples, and hence borderline statistical significance for the up-regulation of abundance of $11 \beta-H S D 1 \mathrm{mRNA}$ in $d b / d b$ mice.

Abundance of mRNA for $5 \alpha \mathrm{R} 1$ was lower in s.c. adipose tissue from obese mice of both strains compared with their respective controls, but was not altered in mesenteric,

Table 1 Body and liver weights and plasma biochemistry of mice

\begin{tabular}{|c|c|c|c|c|}
\hline & $D b / ?$ control & $d b / d b$ & $\mathrm{Ob} /$ ? control & $o b / o b$ \\
\hline Liver $(\mathrm{g})$ & $1 \cdot 31 \pm 0 \cdot 02$ & $2 \cdot 14 \pm 0 \cdot 14^{*}$ & $1 \cdot 41 \pm 0 \cdot 08$ & $3 \cdot 79 \pm 0 \cdot 04^{\dagger}$ \\
\hline Insulin (pg/ml) & $1 \cdot 2 \pm 0 \cdot 2$ & $5 \cdot 5 \pm 0 \cdot 9^{*}$ & $0 \cdot 5 \pm 0 \cdot 1$ & $>12 \cdot 8^{\dagger}$ \\
\hline Liver TAG $(\mu \mathrm{mol} / \mathrm{g})$ & $34 \cdot 7 \pm 3 \cdot 5$ & $728 \pm 178^{*}$ & $36 \cdot 3 \pm 5 \cdot 3$ & $2287 \pm 130^{\dagger}$ \\
\hline Corticosterone $(\mathrm{nM})$ & $7 \cdot 2 \pm 1 \cdot 4$ & $60 \cdot 3 \pm 19 \cdot 5^{* *}$ & $17 \cdot 9 \pm 4 \cdot 7$ & $77 \cdot 4 \pm 16 \cdot 0^{\dagger}$ \\
\hline
\end{tabular}

Data are mean \pm s.E.M., compared by Student's $t$-test. ${ }^{*} P<0 \cdot 005,{ }^{*} * P<0 \cdot 01$ for $d b / d b$ mice versus $D b / ?$ control. ${ }^{\dagger} P<0 \cdot 005$ versus $o b / o b$ mice versus $O b /$ ? control. $N=10-13 /$ group. NB insulin concentrations in all ob/ob mice exceeded the maximum point of the assay. TAG, triglycerides. 

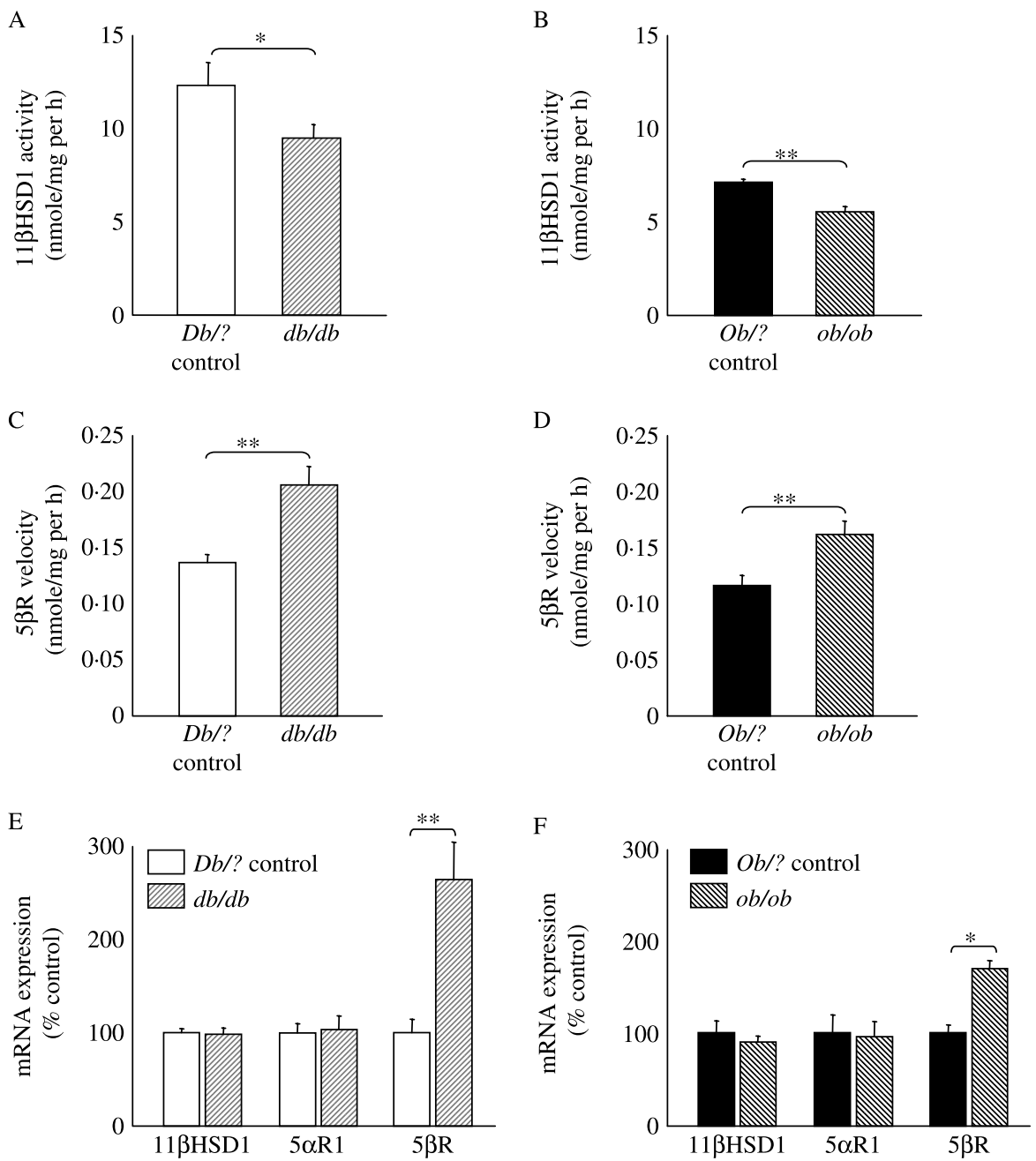

Figure 2 Hepatic glucocorticoid metabolism. 11 $\beta$-HSD1 activity measured as velocity of formation of product following incubation of $\left[{ }^{3} \mathrm{H}_{4}\right.$-corticosterone with hepatic homogenate from (A) $\mathrm{Db} /$ ? control (open) or $d b / d b$ mice (light striped); (B) $O b /$ ? control (black) or $o b / o b$ mice (dark striped). $5 \beta$-Reductase activity measured as velocity of formation of product following incubation of $\left[{ }^{3} \mathrm{H}\right]_{4^{-}}$ corticosterone with hepatic cytosol from (C) $D b /$ ? control or $d b / d b$ mice; (D) $O b /$ ? control or $o b / o b$ mice. Abundance of mRNAs for hepatic enzymes measured by real-time PCR (corrected for $18 \mathrm{~S}$ as a housekeeping gene and presented as a percentage of respective control group) in (E) $\mathrm{Db} /$ ? control or $d b / d b$ mice; (F) $O b /$ ? control mice or $o b / o b$ mice. Data are mean \pm s.E.M.; $n=10-12 /$ group; ${ }^{*} P<0 \cdot 05 ;{ }^{* *} P<0 \cdot 01$.

epididymal or retro-peritoneal adipose tissue in either obese strain (Fig. 3E and F).

Neither $5 \beta$ - nor $5 \alpha$-reductase 2 mRNAs were detected in adipose tissue.

\section{Discussion}

These studies demonstrate that mice with genetic obesity due to either defective leptin secretion $(o b / o b)$ or sensitivity $(d b / d b)$ have similar alterations in $11 \beta-H S D 1$ and $5 \beta \mathrm{R}$ as Zucker obese rats (Livingstone et al. 2005). This includes down-regulation of $11 \beta-H S D 1$ in liver and up-regulation in visceral adipose tissue depots, although in obese mice $11 \beta$-HSD1 was lower in s.c. adipose depots. By contrast with Zucker rats (Livingstone et al. 2005), however, 5 $\alpha \mathrm{R} 1$ expression was not increased in liver of obese mice and was decreased in s.c. adipose tissue. Strikingly, we did not find systematic differences between glucocorticoid metabolism in leptin deficient $o b / o b$ mice and leptin-resistant $d b / d b$ mice. This contrasts with the previous reports suggesting up-regulation of $11 \beta-H S D 1$ in the liver of $d b / d b$ mice (Liu et al. 2005, Nakano et al. 2007), and suggests that enhanced signalling through the short Ob-Ra splice variant does not contribute to 
A

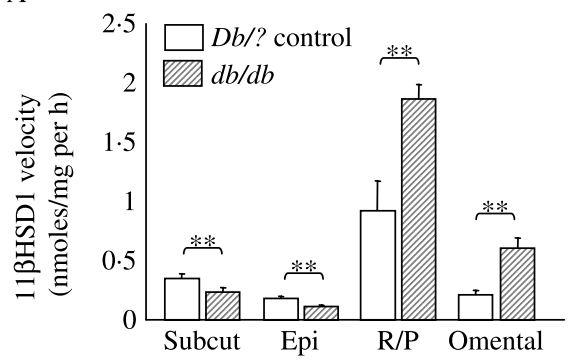

$\mathrm{C}$

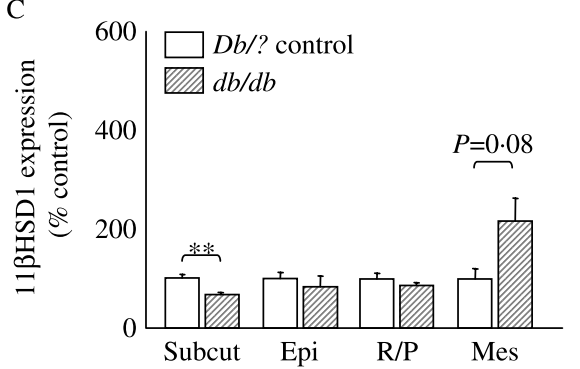

E

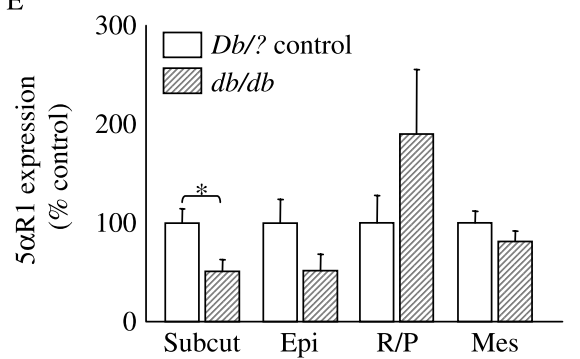

B
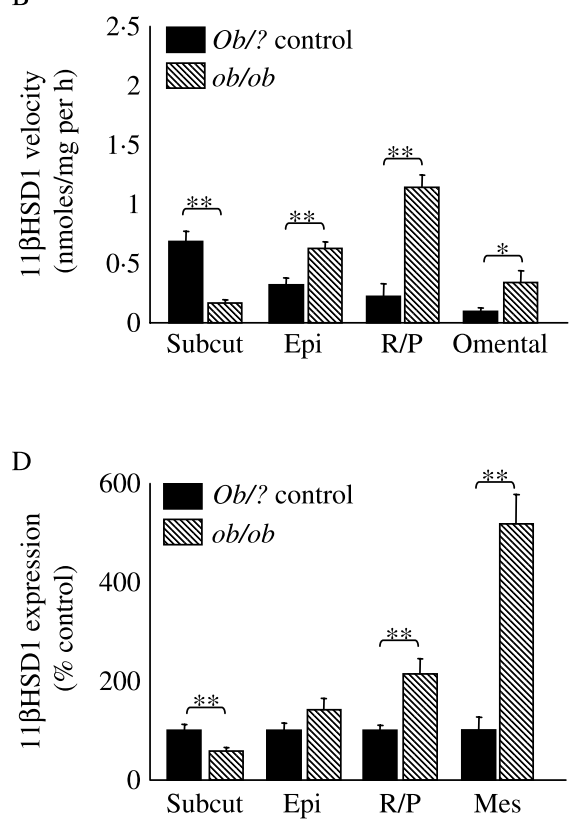

$\mathrm{F}$

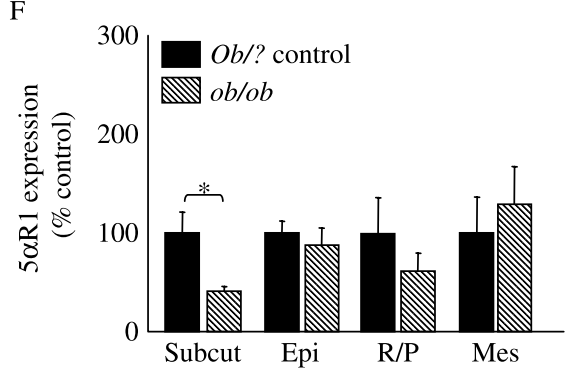

Figure 3 Glucocorticoid metabolism in adipose tissues. 11 $\beta$-HSD1 activity measured as velocity of formation of product following incubation of $\left[{ }^{3} \mathrm{H}\right]_{4}$-corticosterone with homogenates of adipose tissues from (A) $D b /$ ? control (open) or $d b / d b$ mice (light striped); (B) $O b /$ ? control (black) or ob/ob mice (dark striped). Abundance of mRNA for 11 $\beta$-HSD1 in adipose tissue depots measured by realtime PCR (corrected for cyclophilin A as a housekeeping gene and presented as a percentage of respective control group) in (C) $D b /$ ? control or $d b / d b$ mice; (D) $O b /$ ? control or $o b / o b$ mice. Abundance of mRNAs for $5 \alpha-R 1$ in adipose beds measured by real-time PCR (corrected for cyclophilin $A$ as a housekeeping gene and presented as a percentage of respective control group) in (E) $D b /$ ? control or $d b / d b$ mice; (F) $O b /$ ? control or $o b / o b$ mice. Subcut is s.c. adipose, Epi is epididymal, R/P is retro-peritoneal and Mes is mesenteric. Data are mean \pm s.E.M.; $n=6-12 /$ group; $* P<0 \cdot 05 ; * * P<0 \cdot 01$.

the regulation of hepatic glucocorticoid metabolism in vivo. Previously observed effects of leptin administration in vivo to reverse changes in 11ß-HSD1 in ob/ob mice (Liu et al. 2003) may have been mediated indirectly through weight loss and reversal of the metabolic phenotype, which inevitably follow leptin replacement.

The pattern of dysregulation of glucocorticoid metabolism in obese rodents differs in some respects from that in obese humans. In human adipose tissue, up-regulation of s.c. $11 \beta-\mathrm{HSD} 1$ is widely reported but $5 \alpha \mathrm{R} 1$ is not altered (Wake et al. 2007b) and alterations in visceral adipose 11ß-HSD1 are inconsistent (Walker \& Andrew 2006). In human liver, down-regulation of $11 \beta-H S D 1$ and up-regulation of both $5 \alpha \mathrm{R} 1$ and $5 \beta \mathrm{R}$ activity have been reported consistently (Andrew et al. 1998, Fraser et al. 1999, Rask et al. 2001, Tomlinson et al. 2008), and some of these hepatic changes are paralleled here in mice and in our studies of obese Zucker rats (Livingstone et al. 2000, 2005, Barat et al. 2007).

This species specificity provides a potential opportunity to dissect mechanisms determining dysregulation of glucocorticoid metabolism in humans using comparative studies in rodents. However, given limited knowledge of regulation of expression of A-ring reductases, the mechanism of altered A-ring reductase activity in obesity remains uncertain. $5 \beta \mathrm{R}$ is 
transiently up-regulated in rats fed a high-fat diet (Drake et al. 2005), and in humans is selectively up-regulated in insulin resistance associated with fatty liver (Westerbacka et al. 2003). The murine models reported here had markedly fatty liver, moreso than that induced with diet-induced obesity. However, the severity of steatosis was more marked in the $o b / o b$ mice, whereas the activity of $5 \beta$-reductase was increased to a greater extent in $d b / d b$ mice. The $d b / d b$ mice demonstrated partial insulin deficiency, and progression towards hyperglycaemia, whereas the $o b / o b$ mice maintained near to normal glucose concentrations, albeit with higher insulin. This perhaps implicates the elevated insulin concentrations themselves in the dysregulation of steroid metabolism. The other potent regulators of $5 \beta \mathrm{R}$ identified to date are androgens, which imprint permanent downregulation of $5 \beta \mathrm{R}$ in liver following in utero exposure (Einarsson \& Gustafsson 1973, Gustafsson \& Stenberg 1974, Jansson et al. 1985). In addition, withdrawal of androgens increases $5 \beta R$ (Barat et al. 2007). Hence, the observed up-regulation may reflect the characteristic lowering of circulating androgens in obesity (Whitaker et al. 1983, Zumoff et al. 1990).

Regarding the regulation of $5 \alpha \mathrm{R} 1$, these data suggest that the mechanism of dysregulation in human obesity is context and/or species-specific and does not operate in $o b / o b$ or $d b / d b$ mice. A caveat, however, is that protein levels or activity of $5 \alpha \mathrm{R} 1$ might vary in the absence of changes in mRNA, but this cannot be readily tested given the instability of the hepatic $5 \alpha \mathrm{R} 1$ protein ex vivo (Eicheler et al. 1995). Previous reports in both humans and rats support the notion that up-regulation of $5 \alpha \mathrm{R} 1$ is secondary to the development of insulin resistance/hyperinsulinaemia and is reversible on treatment (Tsilchorozidou et al. 2003, Livingstone et al. 2005, Tomlinson et al. 2008). IGF-1 has been suggested as the principle candidate for dysregulation of hepatic $5 \alpha \mathrm{R} 1$ (Horton et al. 1993). However, both mouse strains studied exhibit profound insulin resistance and therefore this explanation may be overly simplistic. Studies of $5 \alpha \mathrm{R}$ s in mouse reproductive physiology have highlighted a possible redundancy between the two isozymes compared with other species (Mahendroo et al. 1996, 2001), but this is unlikely to explain the differences in $5 \alpha \mathrm{R} 1$ dysregulation in obese mice, since the expression of $5 \alpha \mathrm{R} 2$ was not detected in either liver or adipose tissue.

The few reports to date examining $5 \alpha \mathrm{R} 1$ in adipose tissue in humans and Zucker rats suggest that the abundance of transcript is not altered by obesity in s.c. depots (Barat $e t$ al. 2007, Wake et al. 2007b). However, in both $o b / o b$ and $d b / d b$ mice, $5 \alpha \mathrm{R} 1 \mathrm{mRNA}$ was down-regulated selectively in s.c. adipose, again highlighting the differences in regulation in this enzyme between species. In contrast to Zucker rats, in which $5 \alpha \mathrm{R} 1$ expression was increased in omental adipose tissue (Barat et al. 2007), changes in mRNA expression were not observed in the murine mesenteric depot, although the greater omental depot was not studied as a direct comparison due to a paucity of tissue in lean mice.

Regulation of $11 \beta-H S D 1$ transcription has been studied extensively but the basis for tissues-specific dysregulation in obesity remains elusive. Species differences in regulation of $11 \beta-H S D 1$ have been demonstrated, most recently in relation to PPAR agonists (Hermanowski-Vosatka et al. 2000, Wake et al. 2007a). Elevated circulating glucocorticoid levels, that are much more striking in rodent than in human obesity, may contribute since $11 \beta-\mathrm{HSD} 1$ is a glucocorticoid-responsive gene (Low et al. 1994, Jamieson et al. 1995, Voice et al. 1996). The striking observation in murine obesity in the present data is the down-regulation of $11 \beta-\mathrm{HSD} 1$ in s.c. adipose tissue. This has also been observed in diet-induced and in polygenic obesity in mice (Morton et al. 2004, 2005). However in humans, inhibition of $11 \beta-H S D 1$ in s.c. adipose tissue has become an attractive target for restricting glucocorticoid action, with most groups agreeing, that in humans, there is up-regulation of the enzyme in this depot (Paulmyer-Lacroix et al. 2002, Lindsay et al. 2003, Wake et al. 2003). Of interest is the observation that changes in $11 \beta$-HSD1 activity in both obese models are more marked than changes in mRNA, indeed in epididymal fat mRNA was not altered. This discrepancy has been reported by ourselves (Morton et al. 2004) and others (Bujalska et al. 2005, Jang et al. 2006) previously. The relationship between activity and abundance of transcript appears most robust in s.c. adipose in humans (Wake et al. 2003, Goedecke et al. 2006); discrepancies existing at other sites and observed here may reflect an additional level of control of $11 \beta-H S D 1$ protein by post-translational modification, e.g. glycosylation (Opperman et al. 1995). Another source of variation between species and depots is the mixture of cell types. 11ß-HSD1 is expressed in macrophages as well as adipocytes (Gilmour $e t$ al. 2006). There is emerging evidence that some depots, and some animal models are more susceptible to macrophage infiltration in the adipose tissue in obesity (Surmi \& Hasty 2008).

In conclusion, murine obesity is characterised by some but not all of the changes in steroid metabolism that are observed in human obesity. The consequences of disrupted glucocorticoid metabolism in rodents may differ from those in humans, since rodents also exhibit substantially elevated circulating concentrations of corticosterone, contrasting with low to normal circulating cortisol in human obesity (Phillips et al. 2000). Nevertheless, mice may provide useful models in which to investigate dysregulation of $5 \beta \mathrm{R}$ and $11 \beta-\mathrm{HSD} 1$ but not $5 \alpha \mathrm{R} 1$ in liver. None of these changes differ substantially in mice with or without leptin signalling through Ob-Ra. The pattern of dysregulation of metabolism in adipose tissue is, however, subtly different between species, offering the possibility that further comparative biology studies may elucidate relevant mechanisms.

\section{Declaration of interest}

D E W L, S L G, G L C and R A have no conflicts of interest that could be perceived as prejudicing the impartiality of the research reported. Within the past 2 years, B R W has consulted for Astra-Zeneca, Dainippon Sumitomo, Merck, Johnson \& Johnson, Incyte, Ipsen, Roche, Vitae, Wyeth, Zydus 
Research Centre, received lecture fees from Abbott and Bristol Myers Squibb, and received research funding from Wyeth. B RW is an inventor on relevant patents held by University of Edinburgh.

\section{Funding}

This work was supported by the Wellcome Trust (060707 and $\mathrm{VS} / 06 / \mathrm{UED} / \mathrm{A} 8$ ).

\section{Author contribution statement}

D E W L, S L G, G L C contributed to the execution and analysis of the studies. D E W L, B R W and R A contributed to study design, data analysis and interpretation and preparation of the manuscript.

\section{Acknowledgements}

We are grateful to Mrs Carolynn Cairns and Mrs Rachel McDonnell for their excellent technical support.

\section{References}

Alberts P, Engblom L, Edling N, Forsgren M, Klingstrom G, Larsson C, Rönquist-Nii Y, Öhman B \& Abrahmsén L 2002 Selective inhibition of $11 \beta$-hydroxysteroid dehydrogenase type 1 decreases blood glucose concentrations in hyperglycaemic mice. Diabetologia 45 1528-1532.

Andrew R \& Walker BR 2002 Glucocorticoid metabolism in health and disease. Recent Research Developments in Endocrinology 3 425-449.

Andrew R, Phillips DIW \& Walker BR 1998 Obesity and gender influence cortisol secretion and metabolism in man. Journal of Clinical Endocrinology and Metabolism 83 1806-1809.

Barat P, Livingstone DEW, Elferink C, MacDonnell R, Walker BR \& Andrew R 2007 Effects of gonadectomy on glucocorticoid metabolism in obese Zucker rats. Endocrinology 148 4836-4843.

Bujalska IJ, Kumar S \& Stewart PM 1997 Does central obesity reflect 'Cushing's disease of the omentum'? Lancet 349 1210-1213.

Bujalska IJ, Draper N, Michailidou Z, Tomlinson JW, White PC, Chapman KE, Walker EA \& Stewart PM 2005 Hexose-6-phosphate dehydrogenase confers oxo-reductase activity upon $11 \beta$-hydroxysteroid dehydrogenase type 1. Journal of Molecular Endocrinology 34 675-684.

Chua SC, Chung WK, Wu-Peng XS, Zhang Y, Liu S-M, Tartaglia L \& Leibel RL 1996 Phenotypes of mouse diabetes and rat fatty due to mutations in the OB (leptin) receptor. Science 271 994-996.

Cohen B, Novick D \& Rubinstein M 1996 Modulation of insulin activities by leptin. Science 274 1185-1188.

Drake AJ, Livingstone DEW, Morton NM, Andrew R, Seckl JR \& Walker BR 2005 Reduced adipose glucocorticoid reactivation and increased hepatic glucocorticoid clearance as an early adaptation to high fat feeding in rats. Endocrinology 146 913-919.

Eicheler W, Seitz J, Steinhoff M, Forssmann WG, Adermann K \& Aumuller G 1995 Distribution of rat hepatic steroid 5alpha-reductase 1 as shown by immunohistochemistry. Experimental and Clinical Endocrinology and Diabetes 103 105-112.

Einarsson K \& Gustafsson J-A 1973 Neonatal imprinting of liver microsomal hydroxylation and reduction of steroids. Journal of Biological Chemistry 248 4987-4997.

Fraser R, Ingram MC, Anderson NH, Morrison C, Davies E \& Connell JMC 1999 Cortisol effects on body mass, blood pressure, and cholesterol in the general population. American Journal of Physiology. Endocrinology and Metabolism 33 1364-1368.

Gilmour JS, Coutinho AE, Cailhier J-F, Man TY, Clay M, Thomas G, Harris HG, Mullins JJ, Seckl JR, Savill JS et al. 2006 Local amplification of glucocorticoids by 11beta-hydroxysteroid dehydrogenase type 1 promotes macrophage phagocytosis of apoptotic leukocytes. Journal of Immunology 176 7605-7611.

Goedecke JH, Wake DJ, Levitt NS, Lambert EV, Collins MR, Morton NM, Andrew R, Walker BR \& Seckl JR 2006 Glucocorticoid metabolism within superficial subcutaneous rather than visceral adipose tissue is associated with features of the metabolic syndrome. Clinical Endocrinology $\mathbf{6 5}$ 81-87.

Gustafsson J-A \& Stenberg A 1974 Irreversible androgenic programming at birth of microsomal and soluble rat liver steroid metabolism by neonatal testosterone. Journal of Biological Chemistry 249 711-718.

Hermanowski-Vosatka A, Gerhold D, Mundt SS, Loving VA, Lu M, Chen Y, Elbrecht A, Wu M, Doebber T, Kelly L et al. 2000 PPARalpha agonists reduce 11beta-hydroxysteroid dehydrogenase type 1 in the liver. Biochemical and Biophysical Research Communications 279 330-336.

Hermanowski-Vosatka A, Balkovec JM, Cheng K, Chen HY, Hernandez M, Koo GC, Le Grand CB, Li Z, Metzger JM, Mundt SS et al. 2005 11ßHSD1 inhibition ameliorates metabolic syndrome and prevents progression of atherosclerosis in mice. Journal of Experimental Medicine 202 517-527.

Hoggard N, Mercer JG, Rayner DV, Moar K, Trayhurn P \& Williams LM 1997 Localization of leptin receptor mRNA splice variants in murine peripheral tissues by RT-PCR and in situ hybridization. Biochemical and Biophysical Research Communications 232 383-387.

Holmes MC, French KL \& Seckl JR 1995 Modulation of serotonin and corticosteroid receptor gene expression in the rat hippocampus with circadian rhythm and stress. Molecular Brain Research 28 186-192.

Horton R, Pasupuletti V \& Antonipillai I 1993 Androgen induction of steroid $5 \alpha$-reductase may be mediated via insulin-like growth factor-1. Endocrinology 133 447-451.

Jamieson PM, Chapman KE, Edwards CRW \& Seckl JR 1995 $11 \beta$-Hydroxysteroid dehydrogenase is an exclusive $11 \beta$-reductase in primary cultures of rat hepatocytes: effect of physicochemical and hormonal manipulations. Endocrinology 136 4754-4761.

Jang C, Obeyesekere VR, Dilley RJ, Alford FP \& Inder WJ 2006 $11 \beta$-Hydroxysteroid dehydrogenase type 1 is expressed and is biologically active in human skeletal muscle. Clinical Endocrinology 65 800-805.

Jansson JO, Ekberg S \& Isaksson O 1985 Imprinting of growth hormone secretion, body growth, and hepatic steroid metabolism by neonatal testosterone. Endocrinology 117 1881-1889.

Lee G-H, Proenca R, Montez JM, Carroll KM, Darvishzadeh JG, Lee JI \& Friedman JM 1996 Abnormal splicing of the leptin receptor in diabetic mice. Nature 379 632-635.

Lindsay RS, Tataranni A, Permana P, Livingstone DEW, Wake DJ \& Walker BR 2003 Subcutaneous adipose $11 \beta$-hydroxysteroid dehydrogenase type 1 activity and mRNA levels are associated with adiposity and insulinaemia in Pima Indians and Caucasians. Journal of Clinical Endocrinology and Metabolism $\mathbf{8 8}$ 2738-2744.

Liu Y, Nakagawa Y, Wang Y, Li R, Li X, Ohzeki T \& Friedman TC 2003 Leptin activation of corticosterone production in hepatocytes may contribute to the reversal of obesity and hyperglycaemia in leptin deficient ob/ob mice. Diabetes 52 1409-1416.

Liu Y, Nakagawa Y, Wang Y, Sakurai R, Tripathi PV, Lutfy K \& Friedman TC 2005 Increased glucocorticoid receptor and $11 \beta$-hydroxysteroid dehydrogenase type 1 expression in hepatocytes may contribute to the phenotype of type 2 diabetes in $d b / d b$ mice. Diabetes 54 32-40.

Livingstone DEW, Jones GC, Smith K, Andrew R, Kenyon CJ \& Walker BR 2000 Understanding the role of glucocorticoids in obesity: tissue-specific alterations of corticosterone metabolism in obese Zucker rats. Endocrinology $141560-563$.

Livingstone DEW, McInnes KJ, Walker BR \& Andrew R 2005 Increased A-ring reduction of glucocorticoids in obese rats: attenuation by insulin sensitisation. Obesity Research 13 1523-1526.

Low SC, Moisan M-P, Edwards CRW \& Seckl JR 1994 Glucocorticoids and chronic stress up-regulate 11b-hydroxysteroid dehydrogenase activity and gene expression in the hippocampus. Journal of Neuroendocrinology 6 285-290.

Mahendroo MS, Cala KM \& Russell DW 1996 5 $\alpha$-Reduced androgens play a key role in murine parturition. Molecular Endocrinology 10 380-392. 
Mahendroo MS, Cala KM, Hess DL \& Russell DW 2001 Unexpected virilization in male mice lacking steroid $5 \alpha$-reductase enzymes. Endocrinolog $\gamma$ 142 4652-4662.

Morton NM, Paterson JM, Masuzaki H, Holmes MC, Staels B, Fievet C, Walker BR, Flier JS, Mullins JJ \& Seckl JR 2004 Novel adipose tissuemediated resistance to diet-induced visceral obesity in 11beta-hydroxysteroid dehydrogenase type 1-deficient mice. Diabetes 53 931-938.

Morton NM, Densmore V, Wamil M, Ramage L, Nichol K, Bunger L, Seckl JR \& Kenyon CJ 2005 A polygenic model of the Metabolic Syndrome with reduced circulating and intra-adipose glucocorticoid action. Diabetes 54 3371-3378.

Nakano K, Inada Y, Masuzaki H, Tanaka T, Yasue S, Ishii T, Arai N, Ebihara K, Hosada K, Maruyama K et al. 2007 Bezafibrate regulated the expression and enzyme activity of $11 \beta$-hydroxysteroid dehydrogenase type 1 in murine adipose tissue and 3T3-L1 adipocytes. American Journal of Physiology. Endocrinology and Metabolism 292 E1213-E1222.

Opperman UC, Netter KJ \& Maser E 1995 Cloning and primary structure of murine $11 \beta$-hydroxysteroid microsomal carbonyl reductase. European Journal of Biochemistry 227 202-208.

Paulmyer-Lacroix O, Boullu S, Oliver C, Alessi MC \& Grino M 2002 Expression of the mRNA coding for $11 \beta$-hydroxysteroid dehydrogenase type 1 in adipose tissue from obese patients: an in situ hybridisation study. Journal of Clinical Endocrinology and Metabolism 87 2701-2705.

Phillips DIW, Walker BR, Reynolds RM, Flanagan DEH, Wood PJ, Osmond C, Barker DJ \& Whorwood CB 2000 Low birthweight predicts elevated plasma cortisol concentrations in adults from three populations. Journal of Internal Medicine 35 1301-1306.

Rask E, Olsson T, Söderberg S, Andrew R, Livingstone DEW, Johnson O \& Walker BR 2001 Tissue-specific dysregulation of cortisol metabolism in human obesity. Journal of Clinical Endocrinology and Metabolism 86 1418-1421.

Rask E, Walker BR, Söderberg S, Livingstone DEW, Eliasson M, Johnson O, Andrew R \& Olsson T 2002 Tissue-specific changes in peripheral cortisol metabolism in obese women: increased adipose $11 \beta$-hydroxysteroid dehydrogenase type 1 activity. Journal of Clinical Endocrinology and Metabolism 87 3330-3336.

Raubenheimer PJ, Nyirenda MJ \& Walker BR 2006 A choline-deficient diet exacerbates fatty liver but attenuates insulin resistance and glucose intolerance in mice fed a high-fat diet. Diabetes 55 2015-2020.

Sahai M, Malladi P, Pan X, Paul R, Melin-Aldana H, Green RM \& Whittington PF 2004 Obese and diabetic db/db mice develop marked liver fibrosis in a model of nonalcoholic steatohepatitis: role of short-form leptin receptors and osteopontin. American Journal of Physiology. Gastrointestinal and Liver Physiology 287 G1035-G1043.

Da Silva BA, Bjorbaek C, Uotani S \& Flier JS 1998 Functional properties of leptin receptor isoforms containing the Gln-Pro extracellular domain mutation of the fatty rat. Endocrinology 139 3681-3690.

Surmi BK \& Hasty AH 2008 Macrophage infiltration into adipose tissue: initiation, propagation and remodeling. Future Lipidology 3 545-556.
Tomlinson JW, Finney J, Hughes BA, Hughes S \& Stewart PM 2008 Reduced glucocorticoid production rate, decreased $5 \alpha$-reductase activity and adipose tissue insulin sensitization following weight loss. Diabetes 57 1536-1543.

Tsilchorozidou T, Honour JW \& Conway GS 2003 Altered cortisol metabolism in Polycystic Ovary Syndrome: insulin enhances $5 \alpha$-reduction but not the elevated adrenal steroid production rates. Journal of Clinical Endocrinology and Metabolism 88 5907-5913.

Voice MW, Seckl JR, Edwards CRW \& Chapman KE 1996 11beta-Hydroxysteroid dehydrogenase type 1 expression in 2S FAZA hepatoma cells is hormonally regulated: a model system for the study of hepatic glucocorticoid metabolism. Biochemical Journal 317 621-625.

Wake DJ, Rask E, Livingstone DEW, Soderberg S, Olsson T \& Walker BR 2003 Local and systemic impact of transcriptional upregulation of $11 \beta$-hydroxysteroid dehydrogenase type 1 in human adipose tissues in obesity. Journal of Clinical Endocrinology and Metabolism 88 3983-3988.

Wake DJ, Stimson RH, Tan GD, Andrew R, Homer NZM, Karpe F \& Walker BR 2007a Influence of peroxisome proliferator-activated receptor (PPAR) $\alpha$ and $\gamma$ agonists on $11 \beta$-hydroxysteroid dehydrogenase type 1 in vivo in humans. Journal of Clinical Endocrinology and Metabolism 92 1848-1856.

Wake DJ, Strand M, Rask E, Westerbacka J, Livingstone DEW, Soderberg S, Andrew R, Olsson T, Yki-Jarvinen H \& Walker BR $2007 b$ The influence of intra-adipose enzymes generating estrogens and androgens on body fat distribution in idiopathic human obesity. Clinical Endocrinology 66 440-446.

Walker BR \& Andrew R 2006 Tissue production of cortisol by 11betahydroxysteroid dehydrogenase type 1 and metabolic disease. Annals of the New York Academy of Sciences 1083 165-184.

Westerbacka J, Yki-Jarvinen H, Vehkavaara S, Häkkinen A-M, Andrew R, Wake DJ, Seckl JR \& Walker BR 2003 Body fat distribution and cortisol metabolism in healthy men: enhanced $5 \beta$-reductase and lower cortisol/cortisone metabolite ratios in men with fatty liver. Journal of Clinical Endocrinology and Metabolism 88 4924-4931.

Whitaker EM, Shaw MA \& Hervey GR 1983 Plasma oestradiol-17beta and testosterone concentrations as possible causes of the infertility of congenitally obese Zucker rats. Journal of Endocrinology 99 485-490.

Zhao AZ, Shinohara MM, Huang D, Shimizu M, Eldar-Finkelman H, Krebs EG, Beavo JA \& Bornfeldt KE 2000 Leptin induces insulin-like signalling that antagonizes cAMP elevation by glucagon in hepatocytes. Journal of Biological Chemistry 275 11348-11354.

Zumoff B, Strain GW, Miller LK, Rosner W, Senie R \& Seres D 1990 Plasma free and nonsex-hormone-binding-globulin-bound testosterone are decreased in obese men in proportion to their degree of obesity. Journal of Clinical Endocrinology and Metabolism 71 929-931.

Received in final form 9 February 2009

Accepted 13 February 2009

Made available online as an Accepted Preprint 16 February 2009 